\title{
PENGEMBANGAN PERANGKAT PEMBELAJARAN IPA TERINTEGRASI DENGAN PENDEKATAN SAINTIFIK UNTUK MELATIHKAN KEMAMPUAN BERPIKIR KREATIF SISWA KELAS VII SMP
}

\author{
Hanif Rafika Putri ${ }^{1)}$, Muslimin Ibrahim²), Soetjipto ${ }^{3)}$ \\ ${ }^{1)}$ Mahasiswa Program Studi Pendidikan Sains, Program Pascasarjana Universitas Negeri Surabaya \\ ${ }^{2), 3)}$ Dosen Pascasarjana Prodi Pendidikan Sains Univesrtitas Negeri Surabaya \\ E-mail: rafika.putri13@co.id
}

\begin{abstract}
Creative thinking required to be facilitated to students in order they are ready to face the challenge in the future which will be more complicated. The student need to motivated to think divergently, including aspects of originality (authentic, uniqueness idea), fluency (continuity of expressing idea), flexibility (capability to expressing different idea), and elaboration (giving explanation toward created idea). This research aimed to develop integrated science learning materials with scientific approach which feseable to facilitate creative thinking skill of grad VII junior high school. This research is development research, that is developing integrated science learning materials with subject Global Warming including (Syllabus, Lesson Plan, Student Work Sheet, Student Text Book, and creative thinking capability test), by using 4D development model. Target of this research is learning instrument which tested on 35 graders VII junior high school with plan One-Group Pretest-Posttest Design. Data analysis using descriptive qualitative resulting: (a) validation of learning instrument with category valid and very valid; (b) learning realization with good category; (c) positive student response; (d) student creative thinking capability is trained (posttest score 71 which meant creative with N-Gain 0.78). The indicators of creative thinking skill wich get the most significant increase are fluency and flexibility. Elaboration and originality are indicators which have a low increasing score between the pre test and post test. It's because the student mostly are not able to connect their own concept to make the idea clearer and they only focus on the ideas in the book, therefore almost all of their ideas are just the same. The conclusion of this research is that the integrated science learning instrument with subject of Global Warming is proper to be used to facilitate creative thinking skill.
\end{abstract}

\section{Keywords: Learning material, guided inquiry, Mind Mapping, Comprehension of Concept, Creative Thinking.}

Abstrak : Kemampuan berpikir kreatif perlu dilatihkan kepada siswa agar mereka siap menghadapi tantangan pada masa mendatang yang semakin sulit. Siswa perlu didorong untuk berpikir divergen, yang mencakup aspek originality (keaslian, keunikan ide), fluency (kelancaran dalam mengungkapkan ide), flexibility (kemampuan mengungkapkan ide yang berbeda), dan elaboration (pemberian detail dan penjelasan pada ide yang dibuat). Penelitian ini bertujuan untuk mengembangkan perangkat pembelajaran IPA terintegrasi dengan pendekatan saintifik yang layak untuk melatih kemampuan berpikir kreatif siswa SMP kelas VII. Penelitian ini merupakan jenis penelitian pengembangan, yakni mengembangkan perangkat pembelajaran IPA terintegrasi materi Pemanasan Global meliputi (silabus, Rencana Pelaksanaan Pembelajaran (RPP), Lembar Kerja Siswa (LKS), Buku ajar Siswa (BAS), serta tes kemampuan berpikir kreatif), dengan menggunakan model pengembangan 4D. Sasaran penelitian adalah perangkat pembelajaran yang diuji cobakan pada 35 siswa SMP kelas VII dengan rancangan One-Group Pre test-Post test Design. Analisis data secara deskriptif kualitatif dengan hasil: (a) Validasi perangkat pembelajaran dengan kategori valid dan sangat valid; (b) Keterlaksanaan pembelajaran dengan kategori baik; (c) Respon siswa positif; (d) Kemampuan berpikir kreatif siswa secara umum terlatih (skor post test 71 yang berarti siswa mencapai kriteria kreatif dengan $\mathrm{N}$-gain 0,78 ). Indikator kemampuan berpikir kreatif yang mengalami peningkatan paling signifikan antara pre test dan post test adalah aspek kelancaran (fluency) dan fleksibilitas (flexibility). Indikator elaborasi (elaboration) dan keaslian (originality) merupakan indikator yang memiliki peningkatan rendah antara pre test dan pos test, karena masih banyak siswa yang belum bisa menghubungkan konsep yang mereka miliki untuk memperjelas ide dan siswa terpaku oleh beberapa hal yang dijelaskan di buku siswa mengenai cara mengatasi permasalahan dalam materi pemanasan global, sehingga ide mereka banyak yang sama. Simpulan penelitian ini, bahwa perangkat pembelajaran IPA terintegrasi materi Pemanasan Global layak digunakan untuk melatihkan kemampuan berpikir kreatif.

Kata kunci: IPA Terintegrasi, Pendekatan Saintifik, Berpikir Kreatif

\section{PENDAHULUAN}

Pendidikan adalah usaha sadar untuk menyiapkan siswa melalui pengajaran dan latihan bagi peranannya di masa yang akan datang, terutama peranan meraka di masyarakat. Tidak tetutup kemungkinan bahwa masalah dan tantangan yang dihadapi di masa mendatang akan semakin rumit. Dibutuhkan manusia yang tangguh, inovatif serta kreatif untuk menghadapi berbagai masalah dan tantangan agar dapat bertahan hidup dan menjadi manusia yang bermanfaat bagi masyarakat luas 
(Munandar, 1999). Sesuai dengan hal yang telah dipaparkan di atas, maka salah satu tujuan kurikulum 2013 adalah mempersiapkan manusia Indonesia agar memiliki kemampuan hidup sebagai pribadi yang produktif, kreatif dan inovatif.

Tujuan tersebut dapat tercapai apabila dalam penerapan kurikulum 2013 di lapangan, guru mampu melatihkan kepada siswa kemampuan berpikir kreatif. Torrence (1965) mendefinisikan berpikir kreatif adalah sensitif dengan masalah-masalah; mencari informasi dari berbagai sumber eksternal; mencari beberapa solusi; menduga, menciptakan alternatif-alternatif untuk menyelesaikan masalah, menguji dan menguji kembali beberapa alternatif tersebut; menyempurnakannya dan akhirnya mengkomunikasikan hasilnya. Setiap orang memiliki kemampuan untuk berpikir kreatif, tetapi tingkatannya berbeda-beda. Berpikir kreatif merupakan salah satu perkembangan puncak dalam tahap-tahap pertumbuhan seseorang. Ada empat karakter berpikir kreatif menurut Torrance (Filasaime, 2008), yakni (1) Originality yakni keunikan dari ide yang diungkapkan; (2) Fluency yakni kemampuan untuk menciptakan ide sebanyakbanyaknya; (3) Flexibility yakni kemampuan untuk mengatasi rintangan mental saat mengeluarkan ide. Ini ditunjukkan dengan tidak adanya ide yang sama saat seseorang diminta mengungkapkan ide atau pendapatnya; (4) Elaboration ditunjukkan oleh sejumlah tambahan dan detail pada setiap ide sehingga stimulus sederhana menjadi lebih kompleks.

Berpikir kreatif membawa dampak yang positif bagi siswa dan lingkungan sekitarnya. Manfaat berpikir kreatif pada diri sendiri adalah dapat mendorong aktualisasi dan potensi yang dimiliki. Orang yang kreatif akan memberi kepuasan bagi lingkungan sekitar karena tindakan orang tersebut dilakukan dalam waktu yang cepat, memberi hasil yang tepat dan banyak, serta hasil karya yang dihasilkan adalah hasil yang orisinal dan unik (Dharma, 2008). Berpikir kreatif juga diperlukan untuk memecahkan masalah-masalah yang muncul di masyarakat.

Hasil penelitian menunjukkan betapa pentingnya berpikir kreatif, namun pembelajaran di sekolah masih belum memperhatikan hal ini. Pengembangan kemampuan berpikir kreatif di sekolah masih sangat memprihatinkan (Munandar, 1999). Tampak adanya kesenjangan antara tuntutan pengembangan berpikir kreatif dengan kenyataan yang ada. Pembelajaran masih cenderung menghambat pertumbuhan dan perkembangan kreativitas siswa. Contoh kongkrit yang ditemukan peneliti saat melakukan observasi di sekolah adalah masih banyak siswa yang belum berani mengungkapkan ide mereka karena takut salah dan dimarahi oleh guru. Mereka hanya mau mengungkapkan ide mereka saat mereka ditunjuk oleh guru.
Berdasarkan hasil wawancara dengan guru IPA kelas VII di SMP Negeri 22 Surabaya, menunjukkan bahwa (1) pembelajaran IPA baru sampai pada tahap pemahaman konsep, (2) siswa belum berani mengungkapkan ide baru pada saat pembelajaran, (3) siswa belum pernah dilatihkan kemampuan berpikir kreatif, (4) keterbatasan waktu guru IPA untuk mengembangkan perangkat pembelajaran IPA terintegrasi sesuai tuntutan kurikulum 2013.

Tema pada kurikulum 2013 adalah kurikulum yang dapat menghasilkan insan Indonesia yang produktif, kreatif, inovatif, afektif melalui penguatan sikap, keterampilan, dan pengetahuan yang terintegrasi (Mulyasa, 2013). Sejalan dengan tema tersebut, pembelajaran IPA di SMP menurut kurikulum 2013 dilaksanakan secara terintegrasi. Pembelajaran IPA terintegrasi merupakan suatu pendekatan pembelajaran IPA yang menghubungkan atau menyatupadukan berbagai kajian IPA menjadi satu kesatuan kebahasaan. Tema yang dipelajari dalam pembelajaran IPA terintegrasi dikaji dari beberapa bidang ilmu, yakni fisika, kimia dan biologi. Hal ini akan menjadikan pemahaman IPA oleh siswa terbentuk secara utuh, holistik dan tidak terpisah-pisah. Pembelajaran IPA terintegrasi juga akan meningkatkan efisiensi dan efektivitas pembelajaran, meningkatkan minat dan motivasi siswa, serta beberapa kompetensi dasar dapat tercapai sekaligus (Tim IPA Terpadu, 2010).

Pembelajaran IPA terintegrasi cocok digunakan untuk melatihkan berpikir kreatif (Tim IPA Terpadu, 2010). Pembelajaran IPA terintegrasi menekankan pada kemampuan analitik terhadap konsep-konsep yang diintegrasikan, karena dapat mengembangkan kemampuan sintesis dan aplikasi konsep, kemampuan asosiatif, eksploratif dan elaboratif. Pembelajaran IPA terintegrasi juga mendorong siswa tanggap terhadap lingkungannya, sehingga bisa memacu siswa berpikir kreatif untuk menyelesaikan masalah di lingkungan dengan menggunakan konsep IPA yang telah dipelajari. Ini sesuai dengan penelitian yang dilakukan oleh Audrey (2012) menyatakan bahwa pembelajaran dengan IPA terintegrasi dapat menjadikan kemampuan berpikir kreatif siswa berkembang. Ini karena tema yang diangkat dalam pembelajaran IPA terintegrasi dekat dengan kehidupan sehari-hari siswa dan dialami oleh siswa. Siswa merasa tertarik untuk mempelajari konsep-konsep yang dipadukan dalam tema tersebut dan tertantang untuk dapat menyelesaikan masalah yang diangkat dalam tema, sehingga siswa dapat menuangkan ide-ide kreatif mereka dalam hal penyelesaian masalah.

Pembelajaran IPA terintegrasi sebenarnya sudah dirancang dalam silabus kurikulum 2013. Setelah dilakukan pemetaan terhadap KI (Kompetensi Inti) dan KD (Kompetensi Dasar), masih ada beberapa KD yang 
dapat diintegrasikan. Materi yang dipilih dalam penelitian ini adalah Pemanasan Global. Pemanasan Global dipilih karena masih ada beberapa materi yang dapat diintegrasikan dalam materi ini. Materi tersebut diantaranya adalah kosep suhu dan kalor, penyebab dan dampak pemanasan global, serta upaya mengurangi pemanasan global. Pengintegrasian materi-materi tersebut bertujuan agar pembelajaran bersifat lebih efektif dan efisien waktu. Pemanasan global juga merupakan salah satu permasalahan lingkungan yang dihadapi dunia saat ini, sehingga setelah belajar mengenai pemanasan global siswa diharapkan mampu menyumbang ide untuk mengatasi pemanasan global.

Tipe integrasi yang dipilih dalam penelitian ini adalah tipe connectted. Tipe ini dipilih karena dapat memperjelas hubungan antar konsep, sehingga memberi siswa gambaran yang luas tentang konsep yang telah dijelaskan. Siswa juga diberi kesempatan untuk melakukan pendalaman, memperbaiki dan mengasimilasi gagasan secara bertahap (Fogarty, 1991).

Pendekatan saintifik (scientific approach) dalam proses pembelajaran sering disebut-sebut sebagai ciri khas dan menjadi kekuatan tersendiri dari adanya kurikulum 2013 (Kemendikbud, 2013). Pendekatan saintifik memudahkan guru atau pengembang kurikulum untuk memperbaiki proses pembelajaran, dimana melalui metode ini dapat memecah suatu proses ke dalam tahapan-tahapan secara terperinci yang memuat instruksi untuk melaksanakan pembelajaran yang dilakukan oleh siswa (Varelas and Michael Ford, 2008). Pendekatan saintifik yang didasarkan pada proses penalaran harus berbasis pada objek yang empiris, dapat diobservasi, terukur dengan prinsipprinsip penalaran yang spesifik.

Pendekatan saintifik merupakan pembelajaran yang mengadopsi langkah-langkah ilmuwan dalam membangun pengetahuan melalui metode ilmiah. Menurut Kemendikbud (2013), kegiatan pembelajaran yang menggunakan pendekatan saintifik dilakukan melalui proses mengamati, menanya, mengumpulkan informasi, mengaasosiasi, dan mengomunikasikan. Ada beberapa tujuan pendekatan saintifik, yakni (1) meningkatkan kemampuan berpikir tingkat tinggi siswa; (2) membentuk kemampuan siswa dalam menyelesaikan suatu masalah secara sistematik (3) melatih siswa dalam mengomunikasikan ide-ide, khususnya dalam menulis artikel ilmiah. Tujuan di atas menggambarkan bahwa pendekatan saintifik cocok digunakan untuk melatihkan kemampuan berpikir kreatif karena mampu merangsang siswa untuk menyelesaikan suatu masalah dan melatih mereka mengkomunikasikan ide-idenya. Berdasarkan uraian di atas, maka akan dilakukan penelitian dengan judul "Pengembangan Perangkat Pembelajaran IPA Terintegrasi dengan Pendekatan Saintifik untuk
Melatihkan Kemampuan Berpikir Kreatif Siswa Kelas VII SMP”.

\section{METODE PENELITIAN}

Penelitian yang dilakukan merupakan jenis penelitian pengembangan (developmental research) yang mengacu pada model pengembangan 4D yang dimofidikasi sampai pada tahap develop saja, karena hanya diujicobakan pada satu kelas implementasi dengan siswa sebanyak 35 orang.

Ujicoba dilaksanakan di SMP Negeri 22 Surabaya pada semester genap Tahun Pelajaran 2014-2015 dengan menggunakan rancangan penelitian One-Group Pretest-Postest Design. Perangkat pembelajaran beserta instrumen yang dikembangkan kemudian divalidasi oleh dua pakar. Teknik pengambilan data pada penelitian ini adalah dengan observasi, tes dan angket. Materi IPA terintegrasi yang dikembangkan adalah materi pemanasan global dengan model connected.

\section{HASIL PENELITIAN DAN DISKUSI}

Data yang diperoleh dalam penelitian ini meliputi validitas perangkat pembelajaran yang telah dikembangkan (silabus, Rencana pelaksanaan pembelajaran (RPP), buku ajar siswa, Lembar Kerja Siswa (LKS), dan tes kemampuan berpikir kreatif), keterlaksanaan pembelajaran, dan respon siswa serta hasil kemampuan berpikir kreatif akan dijabarkan sebagai berikut:

\section{A. Validitas Perangkat Pembalajaran}

Hasil validasi perangkat pembelajaran yang dikembangkan adalah sebagai berikut: validitas silabus pada setiap aspek yang dinilai memenuhi dua kategori yaitu valid dan sangat valid dengan reliabilitas $99 \%$. Validitas RPP juga dengan kategori valid dan sangat valid dengan reliabilitas sebesar $98 \%$. Sedangkan buku ajar siswa yang digunakan juga memenuhi kategori valid dan sangat valid pada kategori format, isi dan bahasa dengan reliabilitas sebesar $96 \%$. Validitas LKS berkategori valid dan sangat valid dengan reliabilitas $96 \%$. Validitas tes berpikir kreatif pada aspek validitas isi serta bahasa juga berkategori valid dan sangat valid.

\section{B. Kepraktisan Perangkat Pembelajaran}

Kepraktisan perangkat pembelajaran dalam penelitian ini ditinjau dari keterlaksanaan pembelajaran dan respon siswa.

1. Keterlaksanaan Pebelajaran

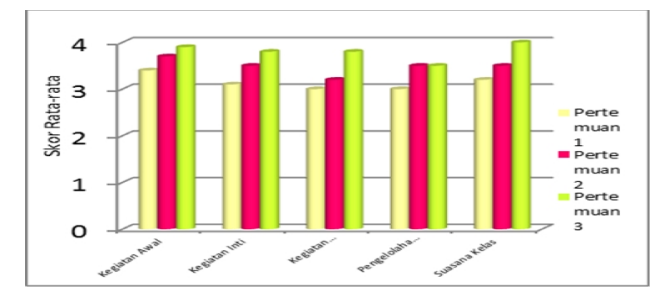

Gambar 2. Diagram Hasil Pengamatan Keterlaksanaan Pembelajaran 
Kepraktisan perangkat pembelajaran ditinjau dari keterlaksanaan rencana pelaksanaan pembelajaran (RPP) dan hasil dari respon siswa terhadap pembelajaran. Berdasarkan hasil pengamatan oleh 2 pengamat pada pertemuan pertama, semua kegiatan pembelajaran di RPP dapat terlaksana, namun nilai yang didapatkan dalam hal pengelolaan waktu masih kurang jika dibandingkan dengan nilai pada aspek yang lain. Ini terjadi karena guru masih beradaptasi dengan siswa. Setelah melakukan evaluasi, pada pertemuan kedua dan ketiga peneliti memperbaiki kekurangan yang terjadi, sehingga pada pertemuan kedua dan ketiga ini terjadi peningkatan skor yang diberikan oleh pengamat dengan skor keterlaksanaan pembelajaran adalah 3 sampai 4 dengan kategori baik dan cukup baik dengan persentase rata-rata reliabilitas $96 \%$. Sehingga, secara keseluruhan kegiatan pembelajaran yang tercantum di RPP dapat terlaksana dengan baik.

RPP yang telah dikembangkan sudah menunjukkan keterpaduan dalam beberapa bidang kajian IPA. Ini terlihat dari materi pembelajaran yang diajarkan ke siswa. Konsep-konsep dari beberapa bidang kajian IPA yakni biologi dan fisika melebur menjadi satu kesatuan dalam materi Pemanasan Global, sesuai dengan definisi IPA terintegrasi sendiri, yakni suatu pendekatan pembelajaran IPA yang menghubungkan atau menyatu padukan berbagai bidang kajian IPA menjadi satu kesatuan bahasan (Tim IPA Terpadu, 2010). Ini akan menjadikan pemahaman IPA oleh siswa akan terbentuk secara utuh, holistik (menyeluruh) dan tidak terpisah-pisah.

Perangkat pembelajaran menggunakan pendekatan saintifik. Pendekatan saintifik merupakan salah satu pendekatan yang digunakan untuk pembelajaran IPA terintegrasi (Muscat, 2012). Pendekatan yang digunakan dalam pembelajaran IPA terintegrasi merupakan pendekatan berbasis inkuiri dan berpusat pada siswa. Pendekatan saintifik yang terdiri atas kegiatan mengamati, menanya, mengumpulkan informasi, mengasosiasi, dan mengkomunikasikan memungkinkan siswa menjadi partner atau teman dalam pembelajaran. Mereka melakukan investigasi terhadap masalah, memperoleh pengetahuan baru mereka secara mandiri dan berusaha menggunakan pengetahuan yang mereka peroleh untuk menyelesaikan masalah yang dihadapi. Siswa juga mengembangkan kemampuan mereka dalam hal berkomunikasi dan mengaitkan IPA dengan peristiwa dalam kehidupan seharihari. IPA terintegrasi memungkinkan siswa memahami pengaruh tindakan manusia terhadap lingkungan alam, memahami hubungan antara alam, kehidupan sosial manusia, dan kebudayaan.

Sesuai dengan pendekatan saintifik, maka hampir semua kegiatan pembelajaran yang terdapat dalam RPP terpusat pada peserta didik, antara lain mereka diminta merumuskan masalah setelah membaca artikel, melakukan kegiatan di LKS untuk membuktikan hipotesis yang mereka buat, kemudian aktif berdiskusi dan membuat simpulan. Semua kegiatan ini sesuai dengan filsafat pendidikan progrevisme yang dikembangkan oleh John Dewey yang menyatakan bahwa pendidikan berpusat pada anak didik. Tujuan pendidikan merupakan rekonstruksi pengalaman yang terus-menerus, agar peserta didik dapat berbuat sesuatu dan mampu mengadakan penyesuaian sesuai dengan tuntutan dari lingkungan (Ornstein \& Levine, 1983). Aliran pendidikan progrevisme merupakan salah satu aliran yang menjadi landasan bagi pembelajaran IPA terintegrasi.

Pembelajaran IPA terintegrasi ini cocok digunakan untuk melatihkan kemampuan berpikir kreatif siswa karena salah satu kelebihan dari pembelajaran IPA terintegrasi adalah mampu melatihkan kemampuan berpikir kreatif siswa. Pembelajaran IPA terintegrasi memadukan berbagai bidang kajian IPA dalam satu satuan. Materi yang diambil pada penelitian aktual dan sesuai dengan masalah dalam kehidupan sehari-hari siswa (Puskur, 2007). Hal ini akan mampu mendorong siswa untuk lebih peka terhadap masalah yang terjadi dalam kehidupan mereka serta mampu memberikan beberapa solusi untuk memecahkan masalah. Untuk menyelesaikan suatu permasalahan, maka diperlukan kemampuan berpikir kreatif agar siswa dapat dengan lancar memberikan dan memilih beberapa alternatif atau cara untuk menyelesaikannya. Ini sesuai dengan penelitian yang dilakukan oleh Audrey (2012) yang mengangkat tema banjir dalam pembelajaran IPA terintegrasi dan hasilnya siswa mampu mengasah kemampuan berpikir kreatifnya dan menuangkannya dalam sebuah games kreatif.

RPP yang dikembangkan dalam penelitian ini juga memuat beberapa tindakan yang dilakukan guru untuk melatihkan kemampuan berpikir kreatif siswa di kelas, seperti mendorong siswa untuk berpikir secara divergen, mendidik siswa untuk bersikap toleransi dengan perbedaan pendapat di kelompok dan diskusi di kelas, serta siswa diberikan bahan, ruang dan waktu untuk melakukan proyek kreatif dengan membuat poster sebagai tugas di rumah. Ini sesuai dengan pernyataan (Fleith; 2000 dan Sattler; 1992) mengenai panduan untuk mendorong berpikir kreatif yang dilakukan oleh guru.

\section{Respon Siswa}

Respon siswa merupakan tanggapan siswa terhadap komponen-komponen perangkat pembelajaran dan suasana pembelajaran yang dilakukan. Respon siswa terhadap pembelajaran IPA terintegrasi materi Pemanasan Global terlihat positif, yakni $83 \%$ siswa yang tertarik terhadap suasana belajar, $97 \%$ siswa menyatakan bahwa cara guru mengajar maupun membimbing jelas, dan $83 \%$ siswa juga setuju jika materi pelajaran lain diterapkan dengan menggunakan pembelajaran IPA terintegrasi dengan menggunakan pendekatan saintifik. Hasil ini sesuai dengan konversi data angket respon siswa menggunakan skala Guttman yaitu interval skor $80 \%-100 \%$ berkategori sangat kuat 
(Riduwan, 2010). Respon siswa terhadap instrumen tes kemampuan berpikir kreatif yang dikembangkan juga terlihat positif, hal ini dibuktikan pada angket respon siswa yang menunjukkan bahwa $71 \%$ menyatakan mudah mengerjakan soal kemampuan berpikir kreatif. Ini karena selama pembelajaran siswa antusias dan aktif dalam pembelajaran. Selama pembelajaran guru juga menciptakan suasana kelas yang mendorong siswa untuk berpikir divergen dan saling toleransi terhadap pendapat saat diskusi kelompok maupun kelas. Pemberian BAS dan LKS yang juga mendorong kemampuan berpikir kreatif siswa menjadikan mereka merasa mudah dan lancar mengerjakan soal kemampuan berpikir kreatif

\section{Kefektifan Perangkat Pembelajaran}

Keefektifan perangkat pembelajaran ditinjau dari peningkatan kemampuan pada indikator berpikir kreatif siswa saat pre test dan post test. Peningkatan hasil belajar siswa juga menunjang keefektifan perangkat pembelajaran yang dikembangkan. Tes yang digunakan untuk menilai kemampuan berpikir kreatif adalah Guilford Alternate Use. Skor dari Guilford Alternate Use yang digunakan berhubungan dengan originality, fluency, flexibility, elaboration (Nur, 2014). Originality, fluency, flexibility, elaboration merupakan karakteristik dari berpikir kreatif.

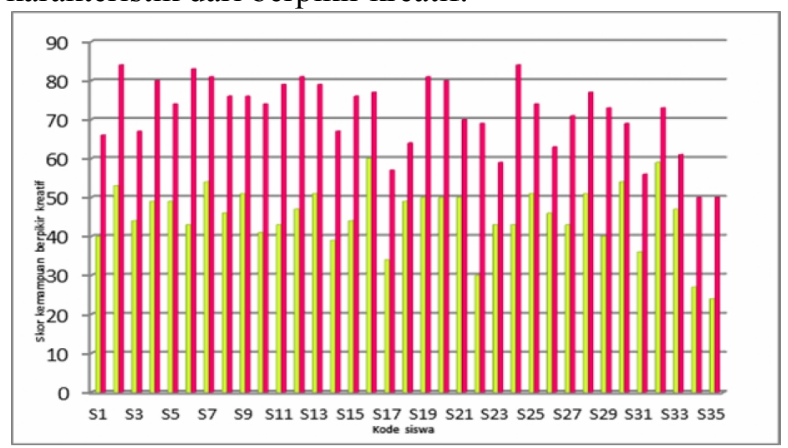

Gambar 3. Diagram tes kemampuan berpikir kreatif siswa

Indikator kemampuan berpikir kreatif yang mengalami peningkatan paling signifikan antara pre test dan post test adalah aspek kelancaran (fluency). Kelancaran merupakan kemampuan untuk menciptakan ide sebanyak -banyaknya. Kelancaran merupakan salah satu indikator yang kuat dari berpikir kreatif. Semakin banyak ide, semakin besar kemungkinan untuk mendapatkan ide yang signifikan. Indikator ini mengalami peningkatan skor yang paling signifikan karena RPP yang telah dikembangkan memuat berbagai tindakan guru saat pembelajaran untuk melatihkan kemampuan berpikir kreatif, salah satunya adalah menerima dan mendorong siswa untuk berpikir divergen dan melakukan sesi curah pendapat untuk menyelesaikan permasalahan yang diangkat dalam buku siswa dan LKS. Kegiatan guru mengajak siswa melakukan sesi curah pendapat untuk menyelesaikan permasalahan merangsang siswa untuk aktif mengungkapkan ide-ide mereka. Kegiatan yang dilakukan berulang-ulang ini menjadikan siswa terbiasa untuk mengungkapkan ide sebanyak-banyaknya (Nur, 2014). Fleksibilitas (Flexibility) merupakan indikator berpikir kreatif yang juga mengalami peningkatan signifikan setelah indikator kelancaran (fluency). Fleksibilitas adalah karakteristik yang menggambarkan kemampuan seseorang untuk mengatasi rintangan mental, mengubah pendekatan untuk sebuah masalah. Fleksibilitas menunjukkan kemampuan siswa dalam mengungkapkan ide yang berbeda untuk menyelesaikan masalah. Selama proses pembelajaran, guru memberikan penekanan kepada siswa bahwa setiap orang mampu mengungkapkan ide kreatif mereka dalam beberapa bentuk.

Indikator elaborasi (elaboration) dan keaslian (originality) merupakan indikator yang memiliki perbedaan skor yang rendah antara pre test dan pos test. Elaborasi (Elaboration) merupakan jembatan bagi seseorang untuk mengkomunikasikan ide kreatifnya kepada masyarakat. Elaborasi ditunjukkan oleh sejumlah tambahan dan detail yang bisa membuat stimulus sederhana menjadi lebih kompleks (Curtis, 2003). Originality ditunjukkan dengan sebuah respon yang tidak biasa, unik dan jarang terjadi. Stimulasi dari ide-ide yang orisinil dapat diperoleh dengan cara berpikir tentang masa depan. Elaborasi menjadi salah satu indikator berpikir kreatif yang memiliki perbedaan skor yang tidak signifikan antara pre test dan post test karena masih banyak siswa yang belum bisa menghubungkan wawasan atau konsep yang mereka miliki untuk memperjelas ide yang mereka ungkap untuk menyelesaikan masalah. Keaslian (originality) merupakan indikator yang paling sulit dilatihkan kepada siswa, ini karena siswa terpaku dan terpengaruh oleh beberapa hal yang dijelaskan di buku siswa mengenai cara mengatasi permasalahan dalam materi pemanasan global. Mereka kebanyakan masih belum bebas mengungkapkan ide mereka karena mereka terpaku bahwa penjelasan di buku siswa adalah ide yang harus diungkapkan saat mengatasi permasalahan, padahal seharusnya masih ada ide yang lain selain dari buku siswa.

Tetapi, secara keseluruhan terdapat peningkatan kemampuan berpikir kreatif siwa pada ujicoba 2 terhadap 35 siswa kelas VII SMPN 22 Surabaya. Tes kemampuan berpikir kreatif siswa pada saat pre-test diperoleh rata-rata 45 dengan kategori cukup kreatif dan pada post-test diperoleh rata-rata 71 dengan kategori kreatif. Perhitungan $\mathrm{N}$-gain menunjukan ratarata 0,78 dengan kriteria tinggi. Uji sensitfitas 5 butir soal tes kemampuan berpikir kreatif menunjukkan nilai rata-rata sensitifitas soal lebih dari 0,3 , sehingga semua 
soal yang dikembangkan dinyatakan sensitif (Gronlund \& Linn, 1995). Hal ini sesuai dengan pernyataan Muslimin (2005), bahwa butir soal yang mampu mengukur kepekaan efek-efek pembelajaran adalah butir soal yang mempunyai nilai sensitivitas $\geq 0.30$. Indeks sensitifitas dari suatu butir soal merupakan ukuran seberapa baik butir soal itu membedakan kemampuan siswa sebelum dan sesudah pembelajaran dengan menggunakan perangkat pembelajaran (Ratumanan, 2011).

Sensitifitas soal berpikir kreatif saat uji coba 1 dan 2 berbeda. Hasil sensitifitas ini berbeda karena saat uji coba 2 guru lebih berpengalaman dalam hal melatihkan kemampuan berpikir kreatif, sehingga siswa yang tadinya kemampuan berpikir kreatifnya rendah dapat mengungkapkan idenya dengan baik sehingga hasil kemampuan berpikir kreatif mereka meningkat saat post test. Hasil ini menunjukkan bahwa pembelajaran IPA terintegrasi materi Pemanasan Global berpengaruh secara signifikan terhadap kemampuan berpikir kreatif siswa. Hal ini sesuai dengan penelitian (Hadzigeorgiou, 2012), bahwa pembelajaran IPA terintegrasi efektif melatihkan kemampuan berpikir kreatif siswa. Audrey (2012) juga berpendapat, bahwa kemampuan berpikir kreatif cocok jika diajarkan dalam pembelajaran IPA karena imajinasi dan kreatifitas merupakan hal pokok yang dipertimbangkan dalam perkembangan natural science atau IPA .

\section{KESIMPULAN}

\section{A. Simpulan}

Berdasarkan hasil penelitian yang telah dilakukan, maka dapat disimpulkan bahwa perangkat pembelajaran IPA terintegrasi materi Pemanasan Global menggunakan pendekatan saintifik yang dikembangkan layak untuk digunakan dalam pembelajaran dan dapat melatihkan kemampuan berpikir kreatif siswa SMP kelas VII.

\section{B. Saran}

Beberapa saran dapat dikemukakan oleh peneliti berdasarkan penelititan yang telah dilakukan adalah sebagai berikut:

1. Penerapan rencana pelaksanaan pembelajaran sudah baik namun guru harus lebih dapat mengelola waktu selama pembelajaran agar pembelajaran bisa berjalan lebih efektif dan efisien.

2. Indikator berpikir kreatif yang paling sulit dilatihkan adalah keaslian dan elaborasi. Keaslian (originality) merupakan indikator yang paling sulit dilatihkan kepada siswa, ini karena siswa terpaku dan terpengaruh oleh beberapa hal yang dijelaskan di buku siswa mengenai cara mengatasi permasalahan dalam materi pemanasan global. Mereka kebanyakan masih belum bebas mengungkapkan ide mereka karena mereka terpaku bahwa penjelasan di buku siswa adalah ide yang harus diungkapkan saat mengatasi permasalahan, padahal seharusnya masih ada ide yang lain selain dari buku siswa. Sedangkan indikator elaborasi sulit dilatihkan karena siswa perlu pemahaman konsep yang kuat agar mampu menambahkan rincian penjelasan dari ide yang mereka ungkapkan. Peneliti lain perlu menekankan kepada siswa pentingnya pemahaman konsep serta keluasan wawasan agar saat memberi ide mereka dapat memberi penjelasan pada masing-masing idenya dengan baik.

\section{REFERENSI}

Bhattacharjee, Pijush Kanti. (2010). Global Warming Impact on The Earth. International Journal of Environmental Science and Development, Vol. 1, No. 3, August 2010. ISSN: 20100264

Depdiknas. (2007). Panduan Pengembangan Pembelajaran IPA Terpadu. Jakarta: Puskur, Balitbang Depdiknas.

Dharma, (2008). Kreativitas. Jakarta: Direktorat Tenaga Kependidikan, Direktorat Jenderal Peningkatan Mutu Pendidik dan tenaga Kependidikan Departemen Pendidikan Nasional.

Filasaime, Dennis, K. (2008). Menguak Rahasia bepikir Kritis dan Kreatif. Jakarta; Prestasi Pustakaraya.

Fledman, Lauren. (2011). Climate on Cable: The Nature and Impact of Global Warming Coverage on Fox News, CNN, and MSNBC. The International Journal of Press/Politics $\mathrm{XX}(\mathrm{X}) 1-29$.

Fogarty, R. 1991. The Mindful School: How To Integrate The Curicula. Palatine: IRI/Skylight Publishing, Inc.

Gronlund, N. E.and Linn, R. L.(1995). Measurement and assesment in teaching(7th ed). New Jersey: Merril Englewood Cliffs.

Hadzigeorgiou, Yannis. (2012). Thinking about Creativity in Science Education. Scientific Research: Creativity Education.

Ibrahim M. (2005). Asesmen Berkelanjutan: Konsep Dasar, Tahapan Pengembangan dan Contoh. Surabaya: Unesa Unirvesity Press.

Kemendikbud. (2013). KURIKULUM 2013. Jakarta: Badan Penelitian dan Pengembangan.

Mulyasa, H. E. (2013). Pengembangan dan Implementasi Kurikulum 2013. Bandung: PT Remaja Rosdakarya. 
Munandar, Utami. (1999). Kreativtas dan Keterbakatan Strategi mewujudkan Potensi Kreatif dan Bakat. Jakarta: Gramedia Pustaka Utama.

Munandar, Utami. (2009). Pengembangan Kreativitas Anak Berbakat Jakarta: Rineka Cipta.

Nur, M. (2014). Berpikir Kreatif Surabaya: Penelitian Unggulan Perguruan Tinggi UNESA.

Ott, jack. (2002). Penilaian Unjuk Kerja (disarikan oleh kusrini \& tatag YES). Surabaya: Pusat Sains dan Matemarika Sekolah Unesa.

Pusat Kurikulum, Balitbang, Depdiknas. (2007). Panduan Pengembanagn Pembelajaran IPA Terpadu, SMP/MTs.

Ratumanan dan Lauren. (2011). Evaluasi Hasil Belajar pada Tingkat satuan Pendidikan Edisi 2. Surabaya. Unesa University Press.

Riduwan. (2010). Skala Pengukuran Variabel-Variabel Penelitian cetakan ke VII. Bandung: Alfabeta.
Rule, Audrey C. (2012). Creativity and Thinking Skills Integrated into a Science Enrichment Unit on Flooding. Scientific Research: Creativity Education

Tim IPA Terpadu. 2010. Draft Panduan Pengembangan Pembelajaran IPA Secara Terpadu. Jakarta : Kementerian Pendidikan Nasional Direktorat Jenderal Manajemen Pendidikan Dasar dan Menengah Direktorat Pembinaan Sekolah Menengah Pertama.

Torrence, E. Paul. (1965). Scientific Views of Creativity and Factors Affecting it's Growth. Daedalus, Vol. 94, No. 3, Creativity and Learning (Summer, 1965), pp. 663-681. American Academy of Arts \& Sciences: The MIT Press.

Varelas, M and Ford M. 2009. The scientific method and scientific inquiry: Tensions in teaching and learning. USA: Wiley InterScience. 